\title{
Establishment of Quercus marilandica Muenchh. and Juniperus virginiana L. in the Tallgrass Prairie of Oklahoma, USA Increases Litter Inputs and Soil Organic Carbon
}

\author{
Vanessa C. Nunes Biral, Rodney E. Will * and Chris B. Zou(D \\ Department of Natural Resource Ecology and Management, Oklahoma State University, 008 Agricultural Hall, \\ Stillwater, OK 74078, USA; nunesbi@ostatemail.okstate.edu (V.C.N.B); chris.zou@okstate.edu (C.B.Z.) \\ * Correspondence: rodney.will@okstate.edu; Tel.:+1-405-744-5444
}

Received: 4 March 2019; Accepted: 9 April 2019; Published: 12 April 2019

\begin{abstract}
The establishment of trees in grasslands alters ecosystem processes and services. Litter inputs shift from herbaceous to tree-derived, which affects the litter quantity and quality and may in turn alter soil carbon dynamics and ecosystem-level carbon sequestration. This study determined changes in the quantity of organic matter inputs following encroachment by two native tree species (Quercus marilandica Muenchh. and Juniperus virginiana L.) into a tallgrass prairie in northcentral Oklahoma, and related it to spatial heterogeneity in soil carbon by measuring variables near the stem, under the tree canopy, at the outer edge of the tree canopy, and beyond the tree canopy. Presence of trees increased aboveground litter inputs (dominated by foliage for J. virginiana and acorns for Q. marilandica) and increased the duff and litter layer. Regardless of leaf litter source, decomposition of foliage was slower under the tree canopy than beyond the tree canopy $(7 \%$ slower) and this change was associated with cooler and potentially drier conditions. However, the foliage of trees decomposed more quickly than grass foliage when measured both beneath and beyond the tree canopy ( $25 \%$ faster). Coarse root biomass was greater under tree canopies than beyond, which increased total root biomass in the deeper soil layer $(10-30 \mathrm{~cm})$. The net effect was an approximately $15 \%$ increase in soil carbon stock under the trees as compared to areas beyond the tree canopy. Therefore, in addition to greater carbon storage in the aboveground biomass, tree encroachment increases carbon sequestration by increasing soil carbon.
\end{abstract}

Keywords: decomposition; soil temperature; soil moisture; soil carbon concentration; soil carbon stock

\section{Introduction}

Trees and grasses co-occur over roughly $1 / 8$ of the Earth's land surface [1]. Over the past century, trees have increased in grasslands and savannas as a result of fire exclusion, grazing, and climate change and is occurring in the Americas, Australia, and Africa, e.g., [2,3]. This process is of global importance in part because it alters carbon cycling and can increase carbon ecosystem storage [1,4]. A region that is undergoing rapid afforestation due to tree encroachment is the southern Great Plains of the USA, which borders the eastern deciduous forest. Grasslands and savannas in this region are undergoing rapid encroachment from native species, such as Juniperus virginiana L. [5], as well as various Quercus spp., such as Q. stellata Wangenh. and Q. marilandica Muenchh. [6].

In particular, J. virginiana encroachment is of regional significance. As of the late 2000s, juniper forests had replaced grasslands on over 130,000 ha in Oklahoma, USA and continued to increase at a rate of approximately 4800 ha year $^{-1}$ [5]. This conversion can happen relatively quickly. For instance, 
in the Flint Hills region of Kansas, USA, grassland converted to closed-canopy J. virginiana forest in 40 years [2].

The encroachment of J. virginiana and other woody plants into the grasslands of the southern Great Plains has profound and dramatic effects on ecosystem functions and services. Conversion from grassland to a closed-canopy J. virginiana stand reduced herbaceous production and species richness [2,7]. When measured at the same research station as the current study, conversion of tallgrass prairie to J. virginiana forest did not alter annual canopy interception of precipitation [8], but did decrease runoff to streams $[9,10]$ probably because of greater transpiration from the evergreen, J. virginiana, which can transpire the majority of incoming precipitation [11]. Juniperus virginiana encroachment also reduces habitat for prairie and savanna fauna [12].

In particular, carbon dynamics and sequestration are dramatically altered by tree encroachment. With J. virginiana encroachment and development of a closed-canopy woodland, aboveground litter inputs increased ten-fold to $500 \mathrm{~g} \mathrm{~m}^{-2}$ year $^{-1}$, litter decay rate decreased, litter C:N decreased, and the soil organic horizon accumulated from near 0 to greater than $1500 \mathrm{~g} \mathrm{~m}^{-2}$ [13]. In addition, aboveground net primary production increased 2 to 3 times, aboveground carbon sequestration increased 10 to 20 times [14], and soil carbon (combined O- and A-horizon) increased by 55\% [15]. However, afforestation is spatially and temporally heterogeneous because the encroachment process occurs at different rates and densities within a given area. Thus, understanding the spatial and temporal variation in soil carbon, the most stable and recalcitrant ecosystem carbon component, is critical to understand changes in the ecosystem carbon status as grasslands convert to woodlands and forests.

Soil carbon changes based on the balance between carbon inputs and decomposition. Thus, understanding aboveground litter inputs and root density as well as the environmental factors that affect decomposition, i.e., moisture and temperature, are essential to understand the mechanisms controlling changes in soil carbon associated with tree encroachment. Under individual J. virginiana trees, soil temperature was lower, incident radiation was reduced $[16,17]$, and throughfall was $25 \%$ to $50 \%$ of incoming precipitation [16], which likely reduces the rate of soil organic matter decomposition. At the same time, greater aboveground litter inputs and the exclusion of fire caused the biomass of the $\mathrm{O}$ horizon to increase [13]. Therefore, soil carbon might increase directly under isolated trees that are encroaching into grasslands. Soil carbon inputs from roots also will differ due to woody plant encroachment. While root turnover rates can vary in ranking between grassland and forest systems, Reich et al. [18] found that standing root biomass was greater, but fine root turnover was lower in a grassland as opposed to the adjacent oak-dominated forest.

The objectives of our study were to: (1) Determine how soil carbon changes $(0-5 \mathrm{~cm}, 5-10 \mathrm{~cm}$, $10-15 \mathrm{~cm}$, and $15-30 \mathrm{~cm}$ ) with proximity to isolated J. virginiana and Q. marilandica trees establishing in a tallgrass prairie of northcentral Oklahoma; (2) characterize how litter inputs and accumulation change with proximity to these isolated trees; (3) quantify decomposition rates of J. virginiana, Schizachyrium scoparium (Michx.) Nash (little bluestem) and Q. marilandica leaf litter; and (4) characterize the distribution and density of fine and coarse root biomass in proximity to trees. We expected that root biomass and aboveground litter inputs would increase with proximity to individual tree stems due to greater inputs as well as slower decomposition, such that soil carbon would be greater near individual tree stems and decline with increasing distance from the stems. Results are important in that they provide an estimate of the spatial variability of carbon content and stock resulting from woody plant encroachment, which is the first step to understanding changes in soil carbon under varying encroachment scenarios.

\section{Materials and Methods}

\subsection{Study Area}

The research was conducted at the Oklahoma State University Cross Timbers Experimental Range Field Station located $15 \mathrm{~km}$ southwest of Stillwater, Payne County, Oklahoma, USA (36 $03^{\prime} 46.73^{\prime \prime} \mathrm{N}$, 
$97^{\circ} 11^{\prime} 03.33^{\prime \prime} \mathrm{W} ; 331 \mathrm{~m}$ above sea level). The mean annual daily temperature is $15.0^{\circ} \mathrm{C}$, with an average daily minimum of $4.3^{\circ} \mathrm{C}$ in January and an average daily maximum of $34.0^{\circ} \mathrm{C}$ in August (Oklahoma Mesonet, Marena station; Oklahoma Climatological Survey). The average annual precipitation is $942 \mathrm{~mm}$ (Oklahoma Mesonet, Marena station; Oklahoma Climatological Survey). The study area is in the transitional zone between the deciduous forest to the east and the prairie to the west and includes a mosaic of both ecosystems. Grassland areas are dominated by $\mathrm{C}_{4}$ grasses, including little bluestem (S. scoparium), big bluestem (Andropogon gerardii Vitman), Indiangrass (Sorghastrum nutans (L.) Nash), switchgrass (Panicum virgatum L.), and tall dropseed (Sporobolus asper (Michx.) Kunth) [7]. Juniperus virginiana trees are present on some parts of the grasslands, as well scattered oaks, including blackjack oak (Q. marilandica), post oak (Q. stellata), and chinquapin oak (Q. muehlenbergii Engelm.).

The study area was cultivated for cotton in the 1930s. As a consequence of the cultivation, severe soil erosion occurred. In the 1950s the agricultural fields were abandoned and naturally re-seeded as prairie. The encroachment of trees on the site started in the 1970s. Prescribed fire, with different return intervals across the area, was introduced in 1983 on a portion of the study area containing a subset of sample trees (additional details below).

\subsection{Tree Selection}

Six replicate trees of $Q$. marilandica and J. virginiana were selected in the grassland area using several criteria. To minimize the influence of other trees, the distance between a study tree and any other tree was greater than the crown radius of the sample tree. For J. virginiana trees, significant noticeable fire impacts to the canopy were avoided. Based on these criteria, three $Q$. marilandica trees were selected from an area with a five-year fire return interval. The other three $Q$. marilandica trees were chosen in an area with no regular fire regime. The six J. virginiana trees were located in an area where fire was applied in the summer. Burning may influence soil carbon. However, for several years before the study, the J. virginiana area was excluded from fire and we specifically chose trees that did not show any signs of previous fire effects indicating minor local impacts on and adjacent to study trees. The area sampled around each tree varied as measurements associated with individual trees were based on positions relative to the canopy radius. At the beginning of the experiment, fencing was installed around individual trees to prevent grazing and interference from cows. While some grazing may have occurred the year before the experiment as cows occasionally moved through the area, grazing pressure was very light and no visible signs grazing were noted at the beginning of the experiment.

The soil series for three trees of each species were Zaneis (fine-loamy, siliceous, active, thermic Udic Argiustolls)-Huska (fine, mixed, superactive, thermic Mollic Natrustalfs) complex. Two Q. marilandica and three J. virginiana were located on the Coyle soil series (fine-loamy, siliceous, active, thermic Udic Argiustolls) and one Q. marilandica was situated on the Renfrow soil series (fine, mixed, superactive, thermic Udertic Paleustolls) (USDA, National Resources Conservations Service, https://soilseries.sc.egov.usda.gov). A Vertex IV hypsometer (Haglöf, Sweden) was used to measure the canopy diameter in the north-south and east-west directions, as well as tree height. Stem diameter was measured with a diameter tape at breast height $(1.37 \mathrm{~m}$ above ground level). Stem age was measured by taking a core with in increment borer at $1.37 \mathrm{~m}$ above ground level. Cores were sanded and annual growth rings counted under magnification. Measurements underestimated age slightly as it takes several years for the trees to reach $1.37 \mathrm{~m}$ tall.

\subsection{Environmental Conditions}

Three of the six study trees of each species were randomly chosen for soil temperature measurements. Twelve ibuttons (DS1921G, Maxim Integrated, San Jose, CA, USA), were placed on the soil surface after the litter layer was removed at three positions along each cardinal direction. The three positions were the midpoint of the canopy, the edge of the canopy, and beyond the tree canopy at a distance equivalent to half the canopy radius. Measurements from the different cardinal directions were averaged according to point position. Another two sensors were placed $5 \mathrm{~cm}$ deep 
in the soil in a northeast direction at positions under the tree canopy and beyond the tree canopy. Measurements were collected every three hours from February to October in 2016, and averaged by week for statistical analysis. Data were reported as the weekly mean temperature.

For all six study trees per species, soil volumetric water content was measured between 0 to $12 \mathrm{~cm}$ using a Hydrosense II (Campbell Scientific, Inc. Logan, UT, USA) at four sample points in each cardinal direction (N, E, S, and W). The four positions were adjacent (approximately $10 \mathrm{~cm}$ ) to the tree stem (point 1), the midpoint of the canopy (point 2), the edge of the canopy (point 3), and beyond the tree canopy at a distance equivalent to half the canopy radius (point 4). Measurements from different cardinal directions were averaged according to the point position. Measurements were collected every two weeks from April to December in 2016.

\subsection{Carbon Inputs}

For all the study trees, eight litter traps of a $30 \times 30 \mathrm{~cm}$ size, made from a plastic basket covered by a fine mesh, were arranged in a northwest to southeast transect. Traps were placed at point 1 (adjacent to tree), point 2 (midpoint of the canopy), point 3 (edge of canopy), and point 4 (beyond canopy). Litter was collected once a month from March 2016 to December 2016. While Q. marilandica may retain its senesced leaves on the tree until early spring, the trees in our study completed abscission before our last litterfall collection. Juniperus virginiana drops litter year round, but January to February is a time of minimal litterfall and represents a small fraction of the annual production. Litter was sorted by species and component, i.e., foliage, reproductive, and twig, dried at $60{ }^{\circ} \mathrm{C}$ until a constant weight was reached, and weighed. The litter collected by the two traps at the same distance was composited as one sample.

The total biomass of the existing litter and duff layer was determined for point 1 (adjacent to the stem), point 2 (midpoint of tree canopy), point 3 (edge of tree canopy), and point 4 (beyond the tree canopy) for each cardinal direction in a $15 \times 15 \mathrm{~cm}$ area during the first week of March 2016. Samples were placed in a paper bag, dried at $60{ }^{\circ} \mathrm{C}$, and weighed. All plants from the $15 \times 15 \mathrm{~cm}$ quadrat were cut at the soil surface, removed, dried at $60{ }^{\circ} \mathrm{C}$, and weighed to estimate herbaceous aboveground net primary productivity (ANPP) for the 2015 growing season. For both the litter/duff layer and understory plants, the four quadrats for each cardinal direction were averaged according to point position.

Root biomass was estimated by measuring fine root ( $<2 \mathrm{~mm}$ diameter) and coarse root $(>2 \mathrm{~mm}$ diameter) size classes. Samples were collected using a sharp, non-curved spade during November 2016 from a $30 \times 30 \mathrm{~cm}$ quadrat for two depths, 0 to $10 \mathrm{~cm}$ and 10 to $30 \mathrm{~cm}$, at points 2 (midpoint of tree canopy) and 4 (beyond the tree canopy) along a northeast to southwest transect (two samples for each position per tree). Soil was sieved to separate roots from soil. Samples were composited by point, depth, and position. After this process, the roots were washed and placed in a drying oven at $60{ }^{\circ} \mathrm{C}$ until they reached a constant weight.

\subsection{Litter Decomposition}

Leaf litter decomposition bags were made from $2 \mathrm{~mm}$ fiberglass mesh approximately $20 \times 20 \mathrm{~cm}$ in size and filled with one of three types of substrate; approximately $40 \mathrm{~g}$ of senesced, air-dried leaf litter from J. virginiana, approximately $12 \mathrm{~g}$ air-dried, senesced litter from Q. marilandica, and approximately $20 \mathrm{~g}$ of air-dried, senesced litter from S. scoparium. Different weights for the three species were used because the bags were filled based on volume. Litter for this portion of the experiment was collected in November 2015 from locations adjacent to the sample trees. One litter bag of each type was placed directly on the soil surface at point 2 (midpoint of tree canopy), point 3 (edge of tree canopy), and point 4 (beyond the tree canopy) in each cardinal direction under each sample tree on March 17, 2016. At the time of field placement, three extra litterbags of each type were returned to the lab and oven dried to determine moisture content at the time of placement. At each collection period, one litter bag of each type was collected from one of the cardinal directions from every tree. The first collection was September 19, 2016, the second collection was December 12, 2016, and the third collection was March 10, 2017. Collected litterbags were placed in a paper bag and oven-dried. The percent of mass loss of 
leaf litter was calculated after correction of the initial weight. It should be noted that the $2 \mathrm{~mm}$ mesh might cause an underestimation of decomposition because the small openings might exclude larger soil mesophauna that play an important role in litter decomposition.

\subsection{Soil Carbon}

Four sample points in each cardinal direction (N, E, S, and W) were sampled for soil organic carbon. Sample points were point 1 (adjacent to the stem), point 2 (midpoint of tree canopy), point 3 (edge of tree canopy), and point 4 (beyond the tree canopy). Soil was collected with a $3.5 \mathrm{~cm}$ diameter soil probe at depths of 0 to $5 \mathrm{~cm}, 5$ to $10 \mathrm{~cm}, 10$ to $15 \mathrm{~cm}$, and 15 to $30 \mathrm{~cm}$ during August 2016. Samples were composited for each radial position and depth combination. The soil was passed through a $2 \mathrm{~mm}$ sieve and visible roots and organic debris were removed. Samples were dried at $60{ }^{\circ} \mathrm{C}$ and ground. Organic carbon fraction was analyzed directly by the loss on ignition method (LECO CN-2000, LECO Corporation, Saint Joseph, MI, USA) by the Soil, Water, and Forage Analytical Laboratory at Oklahoma State University.

To determine soil bulk density, soil cores were taken on positions 2 and 4 along a northeast transect. Samples were taken with a $5 \mathrm{~cm}$ diameter auger to a 0 to $5 \mathrm{~cm}, 5$ to $10 \mathrm{~cm}, 10$ to $15 \mathrm{~cm}$, and 15 to $30 \mathrm{~cm}$ depth during the first week of March 2016. Care was taken to ensure an accurate volume of soil was excavated for each sample. Samples were oven dried at $90^{\circ} \mathrm{C}$ until they reached a constant weight. Bulk density was calculated as dry mass/volume of the soil. Soil carbon content was calculated as bulk density* carbon concentration according to the point and soil depth with the bulk density from point 2 used for calculations for points 1 and 2 and the bulk density from point 4 used to calculate carbon content for points 3 and 4 .

\subsection{Statistical Analyses}

All data were statistically analyzed with software SAS 9.3 (SAS Institute Inc. 2010, Cary, NC, USA) using Proc Mixed. The overall design was a split-plot analysis with species serving as the whole-plot factor and point serving as the split-plot factor. The trees of a given species were spatially separate from those of the other species. Therefore, we make no inference regarding species differences. However, inference regarding whether the effect of point was consistent among the two species, i.e., point $\times$ species interaction, is permitted. When the point $\times$ species interaction was significant, species were analyzed separately. When data included repeated measures, e.g., temperature, a repeated measures component was added using the autoregressive 1 (AR1) covariance structure. When different soil depths were included, e.g., soil carbon, soil depth was added as a second split-plot factor. Data were $\log$ transformed $(\log ($ value +1$))$ as necessary to meet the assumption of homogeneous variance. The sample size for testing point effects was 6 for each species. Given the split-plot approach, the degrees of freedom for tests involving point and involving the point $\times$ species interaction were 3 for the numerator and 30 for the denominator when not considering repeated measures. Degrees of freedom for the denominator increased with repeated measures in accordance with how many times variables were sampled.

\section{Results}

\subsection{Sample Trees}

Diameter at breast height averaged $41.5 \mathrm{~cm}$ for $Q$. marilandica and $35.6 \mathrm{~cm}$ for J. virginiana (Table 1). Heights averaged $8.6 \mathrm{~m}$ and $6.8 \mathrm{~m}$ while canopy diameter averaged $9.1 \mathrm{~m}$ and $8.9 \mathrm{~m}$ for Q. marilandica and J. virginiana, respectively. Average tree age measured at breast height was 41.4 years for Q. marilandica and 38.8 years for J. virginiana (Table 1 ). 
Table 1. Stem diameters measured at $1.37 \mathrm{~m}$ (diameter at breast height; $\mathrm{DBH}$ ), tree height, tree canopy diameter $(C D)$, and tree age.

\begin{tabular}{cccccc}
\hline Species & Tree & DBH $(\mathbf{c m})$ & Height $(\mathbf{m})$ & CD $(\mathbf{m})$ & Age \\
\hline \multirow{5}{*}{ Q. marilandica } & 1 & 26.0 & 7.8 & 7.5 & 40 \\
& 2 & 47.7 & 8.2 & 8.9 & 47 \\
& 3 & 38.7 & 6.1 & 7.8 & $\dagger$ \\
& 4 & 56.6 & 11.5 & 13.4 & 46 \\
& 5 & 52.7 & 11.4 & 10.2 & 45 \\
J. virginiana & 6 & 27.4 & 6.6 & 6.5 & 29 \\
& 1 & 41.5 & 6.0 & 11.0 & $\ddagger$ \\
& 2 & 31.7 & 6.1 & 9.1 & 37 \\
& 3 & 38.1 & 9.9 & 8.4 & 43 \\
& 5 & 34.7 & 8.9 & 7.7 & 35 \\
& 6 & 37.5 & 6.0 & 9.2 & 47 \\
\hline
\end{tabular}

† Hollow center encountered after 35 growth rings; $\ddagger$ No core possible.

\subsection{Environmental Conditions}

Average soil surface temperatures were $23.7^{\circ} \mathrm{C}$ for Q. marilandica and $23.9{ }^{\circ} \mathrm{C}$ for J. virginiana. Differences in soil surface temperature were highly significant among points $(p<0.0001)$ and these differences were similar for the two species (species $\times$ point; $p=0.77$ ). Soil surface temperature increased with increasing distance from the tree trunk; $22.6^{\circ} \mathrm{C}$ for point 2 (midpoint of canopy), $23.9{ }^{\circ} \mathrm{C}$ for point 3 (outer edge of canopy), and $24.9^{\circ} \mathrm{C}$ for point 4 (beyond canopy) (Figure S1). Also, there was a significant difference for the soil surface temperature due to the time of the year $(p<0.0001)$ as it fluctuated from approximately $18{ }^{\circ} \mathrm{C}$ in spring and fall to $30^{\circ} \mathrm{C}$ in the summer. There was an interaction between point and measurement date (point $\times$ week; $p<0.0001$ ) because the temperatures among points were similar during the cooler spring and fall $\left(<1.0^{\circ} \mathrm{C}\right.$ difference), but differences were as large as $4{ }^{\circ} \mathrm{C}$ in summer when temperatures were warmer. Soil temperature at the $5 \mathrm{~cm}$ soil depth followed the same trends and had the same significant factors as soil surface temperature, but was overall cooler, averaging $20.9^{\circ} \mathrm{C}$ for point 2 and $22.6^{\circ} \mathrm{C}$ for point 4 (Figure S2).

Soil moisture decreased significantly from point 4 (beyond the canopy) to point 1 (near the stem) for both tree species $(p<0.0001)$. However, there was a significant species $\times$ point interaction $(p=0.02)$ because the decrease was smaller across the transect for $Q$. marilandica than for J. virginiana. The volumetric water content (VWC) for $Q$. marilandica was $17.1 \%$ for point $1,18.4 \%$ for point $2,18.7 \%$ for point 3 , and $19.5 \%$ for point 4 . The VWC under J. virginiana was $16.4 \%, 17.9 \%, 19.9 \%$, and $21.2 \%$ for points 1, 2, 3, and 4, respectively (Figure S3). There were significant differences among dates $(p<0.0001)$ as soil moisture fluctuated from approximately $5 \%$ to $35 \%$ with season and rainfall events. An interaction between point and week $(p<0.0001)$ was observed because differences among points were small when soils were dry and differences among points were larger when soils were wetter.

\subsection{Carbon Inputs}

Total aboveground litter fall decreased with distance from the tree stem for both species $(p<0.0001)$ with points 1 and 2 similar, point 3 significantly lower, and point 4 significantly lower still (Figure 1 ). The overall reduction from points 1 to 4 for Q. marilandica was $91 \%$ and for J. virginiana was $96 \%$. Litter fall of J. virginiana was dominated by leaf $(81 \%)$ while that of $Q$. marilandica was dominated by acorns $(69 \%)$. When leaf and reproductive tissues were tested separately, both decreased with distance from the stem for both species $(p<0.0001)$. The species $\times$ point interaction was significant $(p<0.0001)$ for leaf and reproductive tissues because the magnitude of change across the transect was proportional to the amount of each tissue type. When leaf and reproductive tissues were analyzed separately, the pattern for both species had similar significance as for total litter fall $(1=2>3>4)$ (Figure 1). 


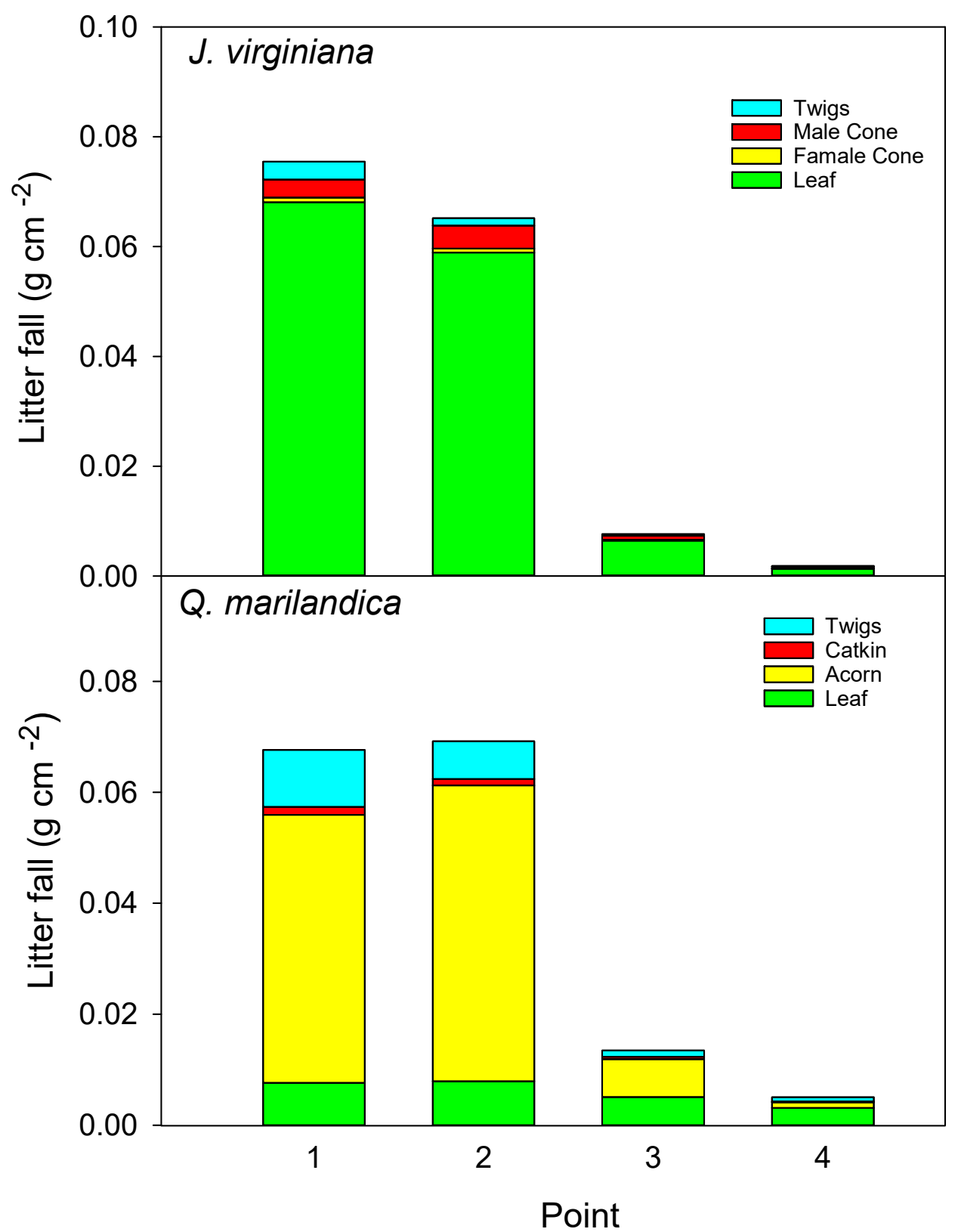

Figure 1. Aboveground litter fall inputs at different distances from isolated stems of J. virginiana and Q. marilandica encroaching in the prairie (collected March to December). Point 1 is adjacent to the stem, point 2 is half way between the stem and the edge of the canopy, point 3 is at the edge of the canopy, and point 4 is beyond the canopy.

Given the pattern of litter fall, it was not surprising that the accumulation of duff and litter increased with proximity to the tree stem $(p<0.0001)$ (Figure 2$)$. The pattern differed slightly between species (species $\times$ point, $p=0.058$ ) because points 1 and 2 were statistically similar for $Q$. marilandica while point 3 and 4 were statistically similar for J. virginiana. The amount of herbaceous vegetation decreased with proximity to tree stems $(p<0.0001)$ and both species exhibited the same pattern (species $\times$ point; $p=0.12$ ) (Figure 2). 


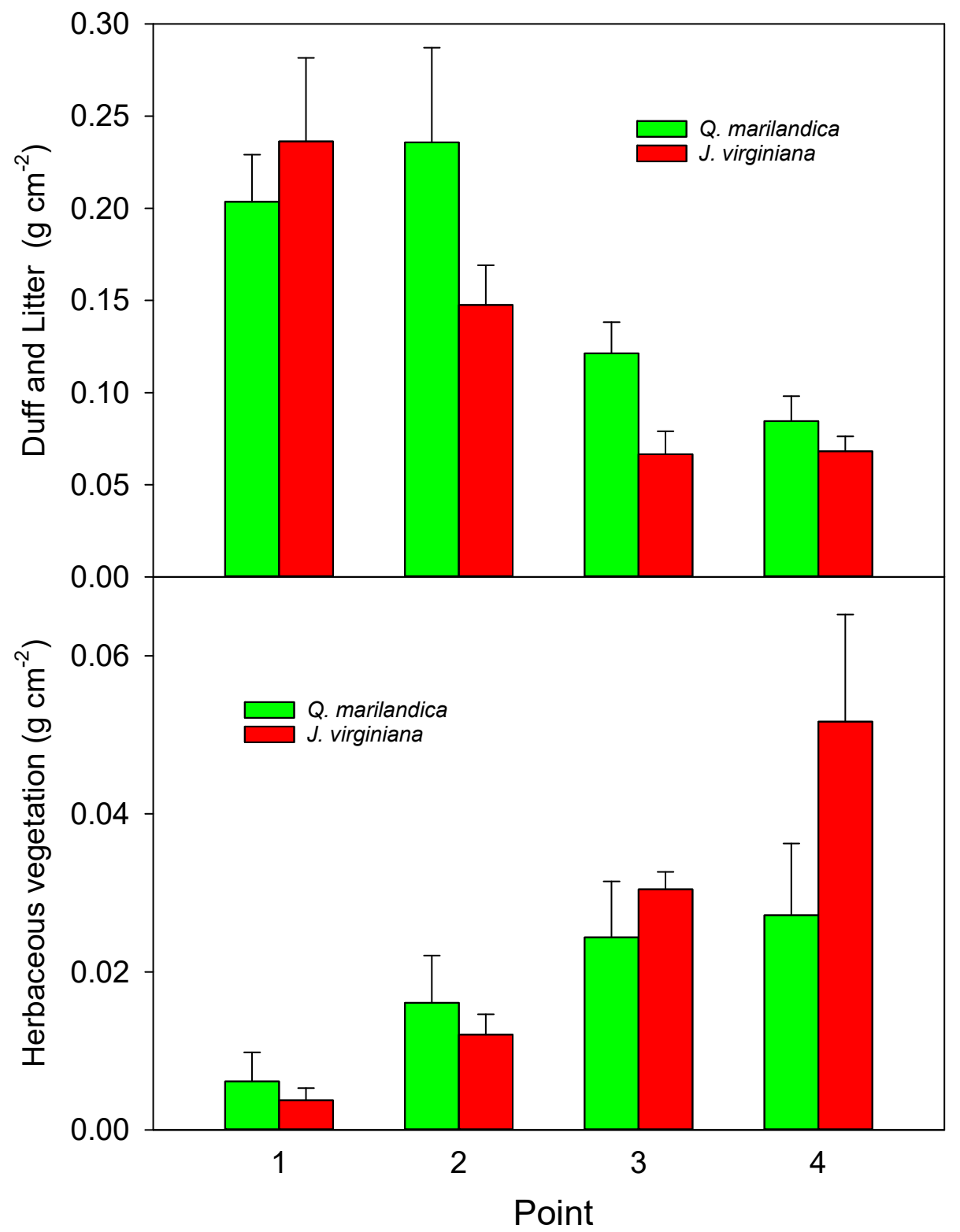

Figure 2. Duff and litter (top) and herbaceous vegetation (bottom) at different distances from isolated stems of J. virginiana and Q. marilandica encroaching in the prairie. Point 1 is adjacent to the stem, point 2 is half way between the stem and the edge of the canopy, point 3 is at the edge of the canopy, and point 4 is beyond the canopy. Vertical bars are standard errors.

Total root biomass measured in a $30 \times 30 \mathrm{~cm}$ area was significantly greater in the upper $10 \mathrm{~cm}$ than in the 10 to $30 \mathrm{~cm}$ layer ( $p=0.04$ ) (Figure 3). The effect of depth was mainly due to differences in fine root biomass. For total root biomass, the interaction between point and depth was significant $(p=0.008)$ because total root biomass was similar among points in the 0 to $10 \mathrm{~cm}$ layer $(p=0.54)$ while total root biomass decreased between point 2 and point 4 for the 10 to $30 \mathrm{~cm}$ soil layer $(p=0.009)$. In the 0 to $10 \mathrm{~cm}$ soil layer, fine root biomass was $80 \%$ greater beyond the canopy (point 4 ) than under the canopy (point 2) ( $p=0.002)$ (Figure 3). In contrast, differences in fine root biomass in the 10 to $30 \mathrm{~cm}$ layer were less than $10 \%$ and not significant $(p=0.89)$. Even though the 10 to $30 \mathrm{~cm}$ soil layer had twice the volume as the 0 to $10 \mathrm{~cm}$ soil layer, the fine root biomass in the 0 to $10 \mathrm{~cm}$ layer was 4.4 times greater than the deeper layer $(p<0.0001)$. Coarse root biomass was 3.8 times greater at point 2 (under the canopy) than at point 4 (beyond the canopy) $(p=0.03$ ) and 2.1 times greater in the 10 to $30 \mathrm{~cm}$ soil layer than in the 0 to $10 \mathrm{~cm}$ soil layer $(p=0.02)$ (Figure 3). If corrected for equal soil volumes, coarse 
root biomass was similar among the two soil depths. If data are calculated on a $\mathrm{kg} \mathrm{m}^{-2}$ basis, the root biomass in the full 0 to $30 \mathrm{~cm}$ layer were $0.77,0.64,0.67$, and $0.43 \mathrm{~kg} \mathrm{~m}^{-2}$ for Q. marilandica一point 2, Q. marilandica-point 4, J. virginiana - point 2, and J. virginiana-point 4, respectively.

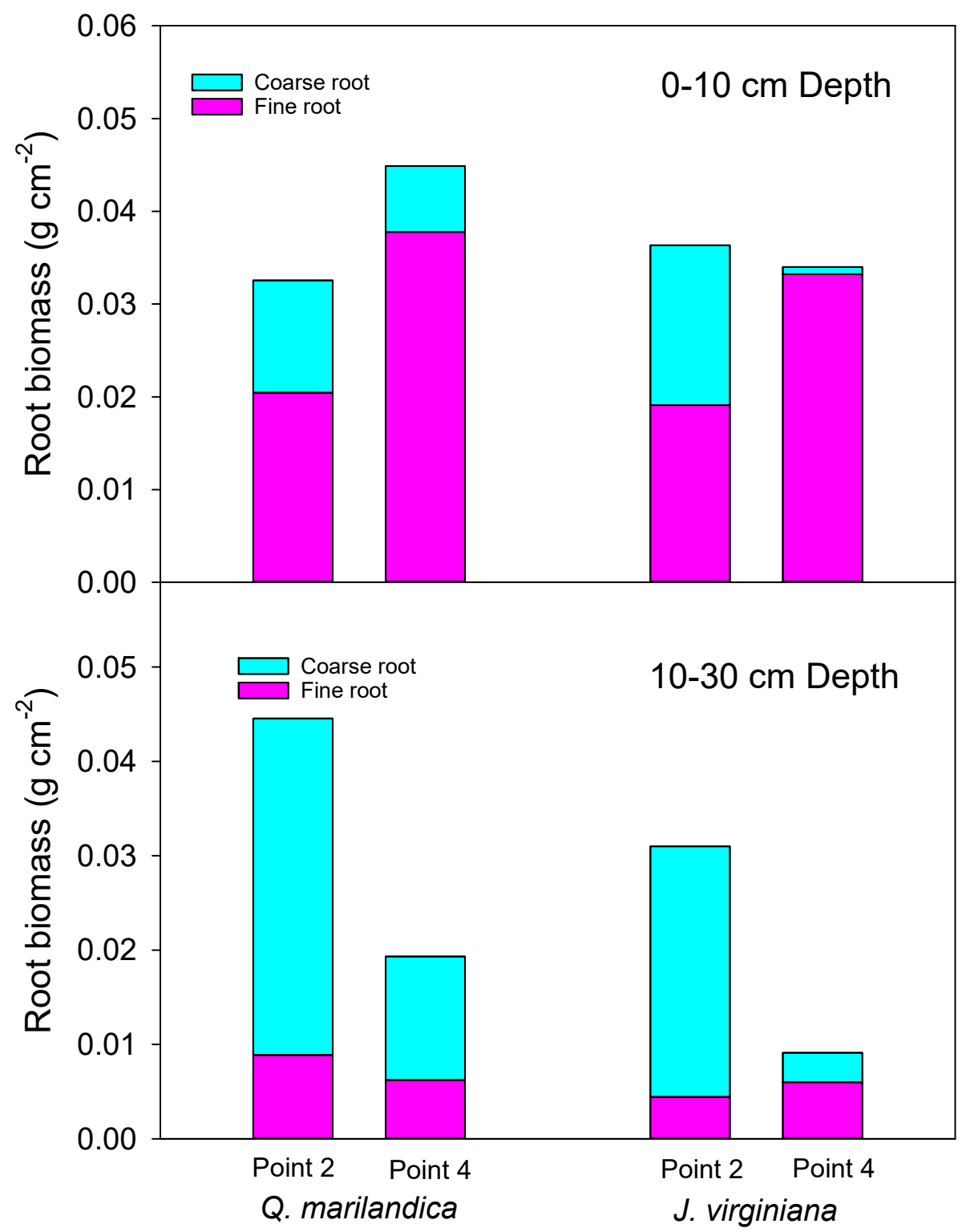

Figure 3. Standing biomass of fine $(<2 \mathrm{~mm}$ diameter $)$ and coarse roots ( $>2 \mathrm{~mm}$ diameter $)$ at different distances from isolated stems of J. virginiana and Q. marilandica encroaching in the prairie. Point 2 is half way between the stem and the edge of the canopy and point 4 is beyond the canopy.

\subsection{Litter Decomposition}

There was a significant difference in the leaf litter decomposition among points $(p=0.01)$, litter type $(p<0.0001)$, date $(p<0.0001)$, and date $\times$ litter type $(p=0.003)$. All other factors and interactions were not statistically significant $(p>0.05)$. The effect of date was significant because the mass remaining declined from $69.4 \%$ to $61.4 \%$ between the collection at 6 months and the collection at 12 months. The date $\times$ litter type interaction was significant because the differences among litter types got larger as time progressed and more litter decomposed. For clarity of the presentation, only the last sample date (12 months after initial placement) is discussed regarding the point and litter type effects (Figure 4). Juniperus virginiana leaf litter decomposed the most (49.7\% remaining) followed by $Q$. marilandica (63.1\% remaining) and S. scoparium (71.0\% remaining). Overall, litter decomposition was least at the 
point under the tree canopy (point 2) than at the drip line (point 3) or the point beyond the dripline (point 4). After 12 months, the mass remaining was $64.6 \%$ for point $2,59.1 \%$ for point 3 , and $60.3 \%$ for point 4 . These responses were consistent among the two species (Figure 4).

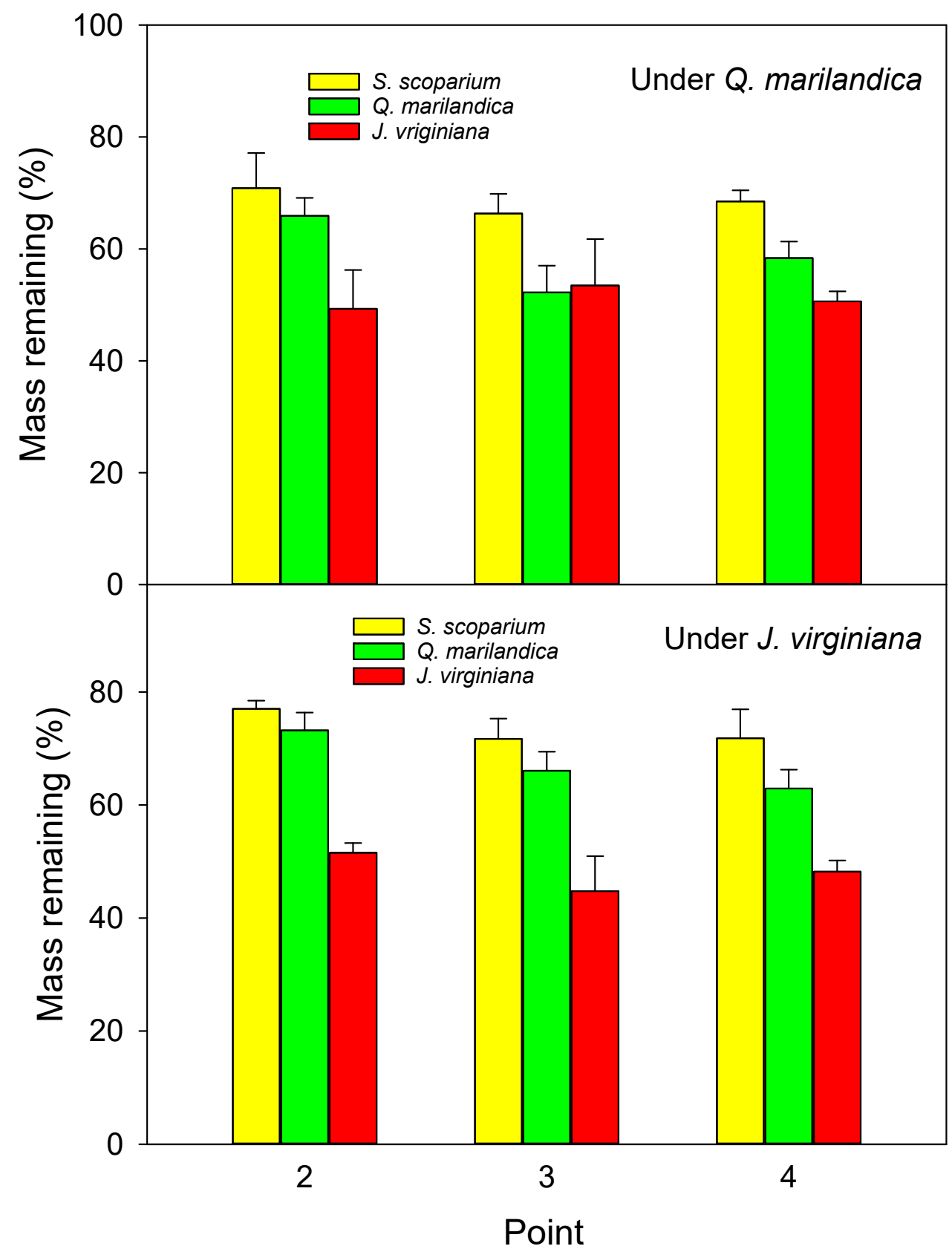

Figure 4. Percent of litter remaining after 12 months of decomposition when three species of leaf litter were placed under isolated J. virginiana and Q. marilandica encroaching in the prairie. Point 1 is adjacent to the stem, point 2 is half way between the stem and the edge of the canopy, point 3 is at the edge of the canopy, and point 4 is beyond the canopy. Vertical bars are standard errors.

\subsection{Soil Carbon}

Soil carbon concentration significantly decreased with each successive soil depth $(p<0.001)$ (Figure 5). The concentration in the 0 to $5 \mathrm{~cm}$ layer was $2.79 \%$, in the 5 to $10 \mathrm{~cm}$ layer was $1.37 \%$, in the 10 to $15 \mathrm{~cm}$ layer was $1.12 \%$, and in the 15 to $30 \mathrm{~cm}$ layer was $1.02 \%$. Soil carbon concentration was greater at the two points under the canopy (point $1=1.72 \%$, point $2=1.64 \%$ ) than at the edge of the 
canopy (point $3=1.48 \%$ ) or beyond the canopy (point $4=1.47 \%)(p=0.011)$. Interactions among species, point, and depth were all not significant $(p>0.21)$.

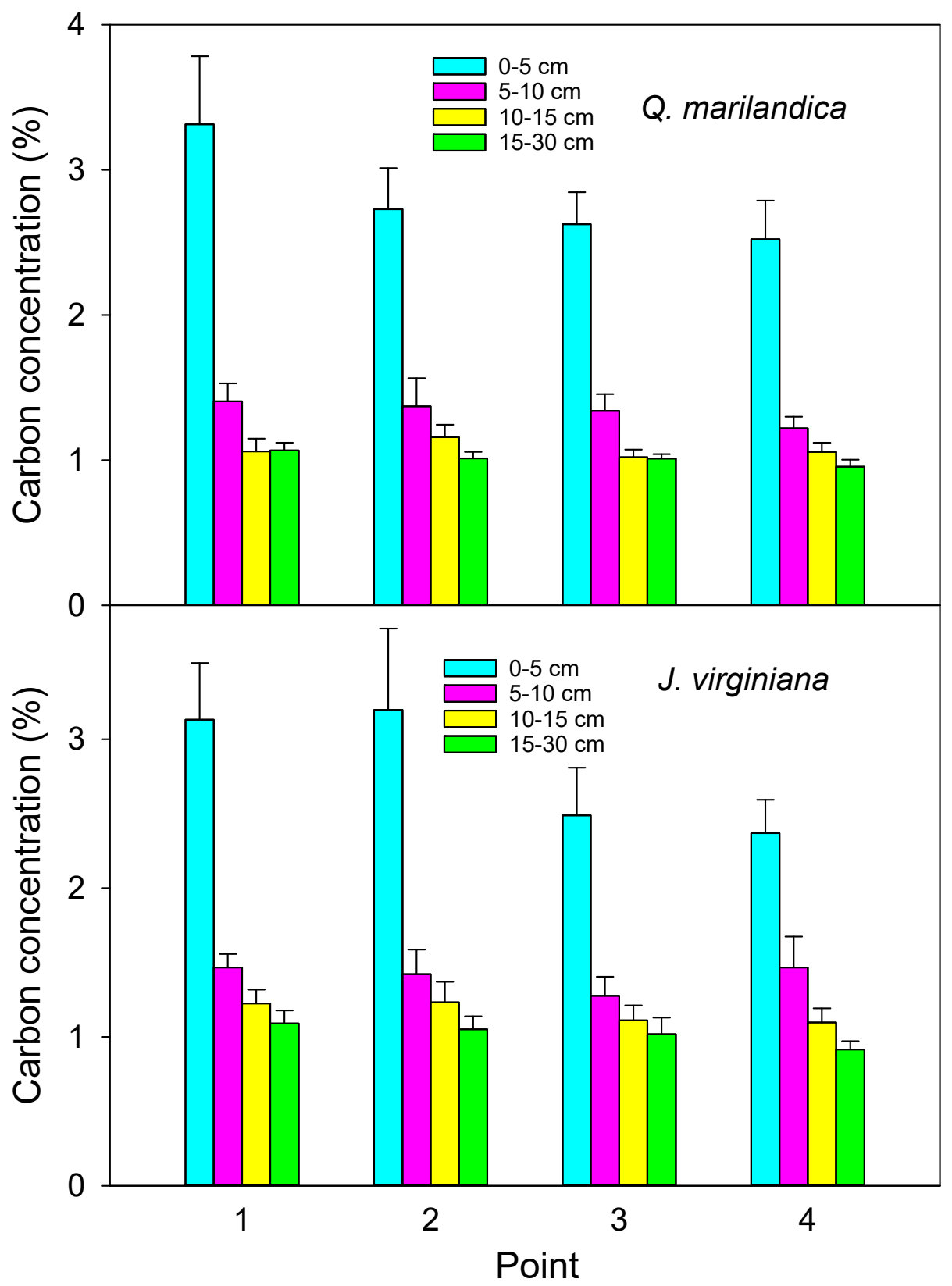

Figure 5. Soil carbon concentration measured at different depths for different distances from isolated stems of J. virginiana and Q. marilandica encroaching in the prairie. Point 1 is adjacent to the stem, point 2 is half way between the stem and the edge of the canopy, point 3 is at the edge of the canopy, and point 4 is beyond the canopy. Vertical bars are standard errors.

Soil bulk density did not differ among points $(p=0.39)$ and this response was consistent among species (species $\times$ point interaction; $p=0.29$ ). Bulk density increased with soil depth $(p<0.0001)$. Bulk density was $1.28 \pm 0.04$ s.e. $\mathrm{g} \mathrm{cm}^{-3}$ for the 0 to $5 \mathrm{~cm}$ layer, $1.42 \pm 0.04$ s.e. $\mathrm{g} \mathrm{cm}^{-3}$ for the 5 to $10 \mathrm{~cm}$ layer, $1.49 \pm 0.02$ s.e. $\mathrm{g} \mathrm{cm}^{-3}$ for the 10 to $15 \mathrm{~cm}$ layer, and $1.47 \pm 0.04 \mathrm{s.e.} \mathrm{g} \mathrm{cm}^{-3}$ for the 15 to $30 \mathrm{~cm}$ layer. Interactions involving soil depth were not significant $(p>0.30)$.

Soil organic carbon stock in the upper $30 \mathrm{~cm}$ decreased with increasing distance from the tree stem $(p=0.002)$ and this was consistent among the two species (species $\times$ point interaction; $p=0.44$ ) (Figure 6). The overall means were $0.627,0.599,0.550$, and $0.544 \mathrm{~g} \mathrm{~cm}^{-2}$ for points 1, 2, 3, and 4, 
respectively, with points 1 and 2 statistically similar $(p=0.19)$ and points 3 and 4 statistically similar $(p=0.83)$, but points 1 and 2 greater than points 3 and $4(p<0.05)$.

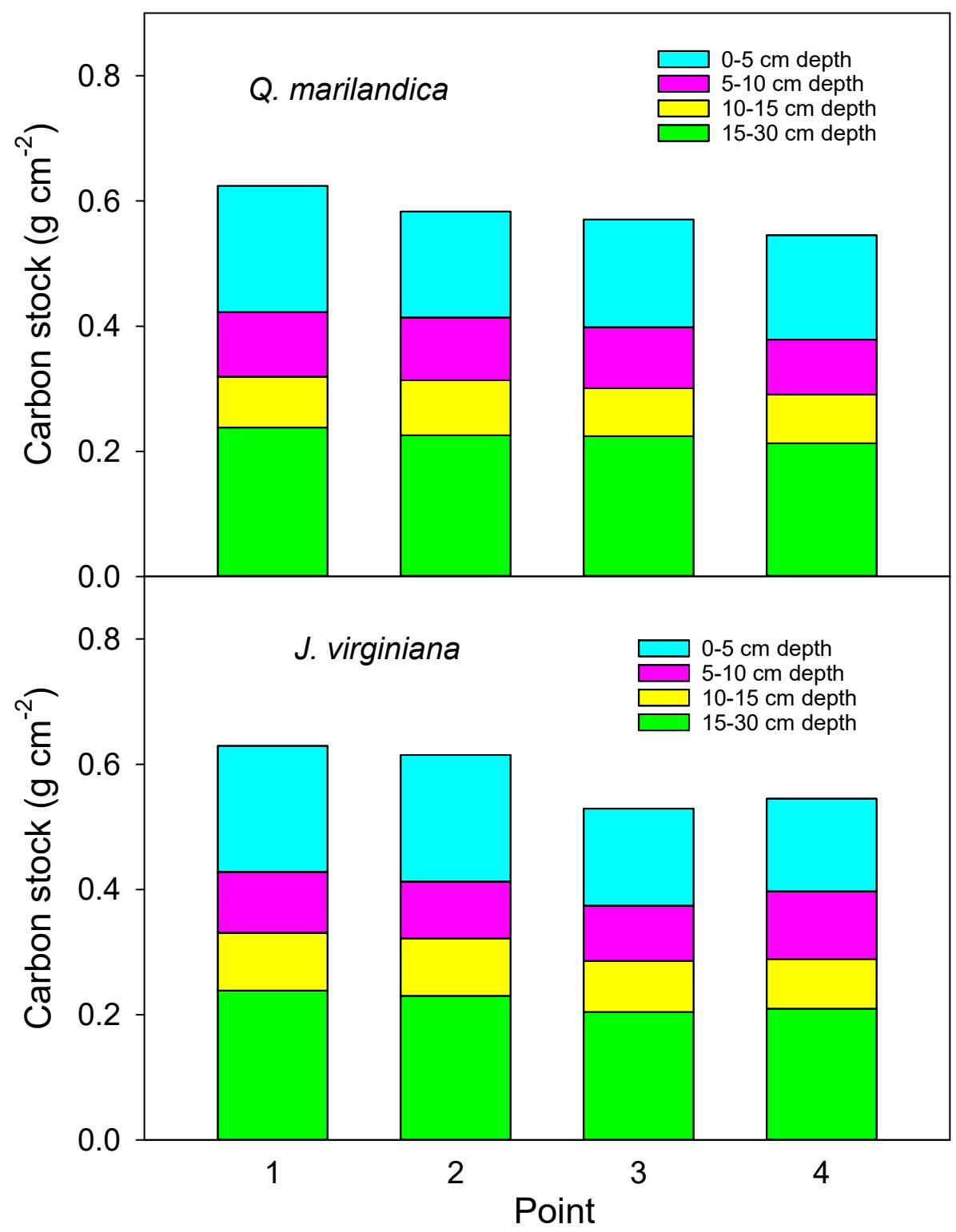

Figure 6. Carbon stock in upper $30 \mathrm{~cm}$ of the soil measured at different distances from isolated stems of J. virginiana and $Q$. marilandica encroaching in the prairie. Point 1 is adjacent to the stem, point 2 is half way between the stem and the edge of the canopy, point 3 is at the edge of the canopy, and point 4 is beyond the canopy.

\section{Discussion}

We found that soil carbon concentration and carbon stock beneath encroaching trees was greater than in the adjacent grassland areas. This is probably due to increased aboveground and belowground inputs. Aboveground litter inputs were approximately $50 \%$ greater under trees than for herbaceous annual aboveground productivity beyond the tree canopies. Root biomass was greater in the deeper soil layer under trees than beyond the tree canopy. While leaf litter decomposition was slightly slower under trees, probably due to cooler and drier soil conditions, the much faster rate of the tree foliage decomposition, as compared to grass, indicates a faster turnover and possible incorporation of recalcitrant humus into the soil. The net result was carbon stock that was $15 \%$ greater adjacent to tree stems than beyond the tree canopy drip line after approximately 40 years of tree influence. 
Soil carbon beneath pasture or grasslands can be greater than under adjacent forest or tree plantations (see meta-analysis [19]). However, the increase of soil carbon under trees encroaching into grasslands that we found is supported by previous studies, e.g., [20-24]. Differences could be related to the fact that we measured the effects of encroaching trees, not the effects of forest conversion to pasture or forest plantation. Likewise, soil type, land use history, and climate could influence the direction of change. Our study site was previously farmed for cotton in the early 1900s, which likely depleted soil carbon stocks, such that we were starting from a relatively low carbon state. Our annual precipitation is near the predicted threshold whereby woody plant encroachment could either increase or decrease soil carbon [25]. Study locations with annual precipitation greater than ours likely would lose soil carbon with woody plant encroachment.

Comparing similar studies examining Juniperus encroachment in the USA, McKinley and Blair [15] found increases in soil carbon similar in magnitude when comparing closed-canopy J. virginiana woodlands adjacent to tallgrass prairie areas in Kansas, USA. In contrast, Pierce and Reich [17] did not find significant differences in soil carbon near individual encroaching J. virginiana trees, but only compared locations at the dripline to areas beyond the dripline. Following a similar protocol, we also would not have found differences, i.e., point 3 (at the edge of the canopy) and point 4 (beyond the canopy) were similar in our study, emphasizing the relatively fine spatial scale of soil carbon change with early stages of woody plant encroachment. Klemmedson and Tiedemann [20] measured the spatial pattern of carbon surrounding encroaching J. occidentalis (Hook.) trees in eastern Oregon and found larger differences in soil organic carbon than we did (30\% to $100 \%$ greater near the stem than at the dripline). The reason for the greater difference could be that their study was in a more arid, lower productivity system (266 cm annual precipitation), such that the effects of trees on soil carbon were greater. Tree encroachment into arid and semiarid regions is known to produce a "fertile island" around individual trees (e.g., [20]).

Jackson et al. [25] found a negative relationship between mean annual precipitation and soil organic carbon change associated with woody plant encroachment in Texas, USA. Their relationship predicts a small decrease in soil carbon due to woody plant encroachment given our annual precipitation ( 940 mm). The fact that we and others, e.g., [15,19], found increased soil carbon in the southern Great Plains associated with the encroachment of woody species indicates that the finding of Jackson et al. [25] may not be generally applicable throughout the region and may depend on factors, such as previous land use history, the potential evapotranspiration/annual precipitation, time since encroachment, and soil type.

The increase in soil carbon stock of approximately $15 \%$ adjacent to stems was consistent for both Q. marilandica and J. virginiana in our study. Given spatial heterogeneity in soil carbon measurements, an increase of $\sim 15 \%$ of soil carbon may sometimes not be statistically conclusive. For instance, Smith and Johnson [23] found a similar $\sim 15 \%$ increase in soil carbon under J. virginiana forest compared to tallgrass prairie, but concluded that there was no effect based on associated variability and lack of statistical differences. While modest, the increase in soil carbon under the trees we measured, combined with much greater carbon storage in the aboveground biomass of trees [14] results in greater carbon sequestration in forest ecosystems that develop as a result of woody plant encroachment.

The additional soil carbon we found associated with encroaching trees was likely due to greater inputs from the trees. Using the different carbon isotope signatures of the $C_{4}$ grasses and the $C_{3}$ J. virginiana, McKinley and Blair [15] determined that an increase in soil carbon in J. virginiana woodlands was primarily due to increased tree inputs, particularly in the upper $2 \mathrm{~cm}$ of the soil. Greater inputs in our study were associated with aboveground, and likely belowground, sources as well.

Total aboveground litter input was greater under trees than in grasslands (assuming herbaceous ANPP is equivalent to aboveground litter inputs in non-burned prairie). When converted to a $\mathrm{g} \mathrm{m}^{-2}$ year ${ }^{-1}$ basis, litter inputs directly beneath the trees was approximately $700 \mathrm{~g} \mathrm{~m}^{-2}$ year $^{-1}$ and herbaceous productivity beyond the canopy was approximately $400 \mathrm{~g} \mathrm{~m}^{-2}$ year $^{-1}$ on average (no fire or grazing). Results for J. virginiana corroborate Norris et al. [13], who found an annual litter production 
of $500 \mathrm{~g} \mathrm{~m}^{-2}$ year $^{-1}$ for J. virginiana woodlands and $52 \mathrm{~g} \mathrm{~m}^{-2}$ year $^{-1}$ for a grassland in Kansas, USA. Acorns were the primary source of aboveground inputs for $Q$. marilandica. The greater biomass of acorns than leaves contradicts Lang [26], who found that leaf biomass was the major component of litter fall in a closed-canopy, mixed-oak forest in New Jersey, USA. Given that we measured acorn production for just one year and because oaks are known to exhibit high annual variability in acorn production, we do not know whether our results are typical. One explanation for the relatively low leaf litter collection is that single oak trees encroaching into grasslands are exposed to high winds, which blow leaves away from the tree and undoubtedly reduced the litter input near trees in our study. In contrast, leaf litter of J. virginiana is smaller and has a needle/scale-like leaf morphology, which reduces its potential for wind driven off-site movement.

Coarse root biomass is predominantly from trees, while fine root biomass is produced by both herbaceous vegetation and trees. Not surprisingly, therefore, coarse root biomass was greater under the tree canopy when compared to the point beyond the tree dripline. Moreover, the majority of coarse root biomass was distributed in the 10 to $30 \mathrm{~cm}$ soil depth. These results agree with Ansley et al. [27], who also observed greater coarse root biomass in deeper soil profiles associated with Prosopis glandulosa Torr. in Texas, USA. On the other hand, fine root biomass was concentrated in the upper $10 \mathrm{~cm}$ of soil. The increase in fine root biomass in the upper soil layer with distance from trees was probably due to the co-occurrence of grass and tree fine roots beyond the dripline and the fact that grasslands often have greater standing root biomass than forests [28,29].

In the context of carbon inputs to soil, root turnover, rather than standing root biomass, is probably more important. While some studies found faster root turnover in grasslands than forests, (e.g., [28,29]), a robust meta-analysis looking at patterns of fine root turnover found that tree fine roots typically have faster turnover rates than fine roots in grassland systems in temperate regions, especially when restricting tree fine roots to a $<2 \mathrm{~mm}$ diameter [30]. The faster turnover rate of tree roots may have increased fine root inputs near the trees even though there was greater standing fine root biomass beyond the canopy. In an area with similar conditions to ours in Wisconsin, USA, Reich et al. [18] found greater fine root biomass in grass-dominated areas when compared to tree-dominated areas. The authors attributed the greater fine root biomass under grass-dominated areas to slower fine root turnover, not greater belowground net primary production. We did not measure root exudates, mycorrhizal biomass, or other non-root carbon inputs, which also affect soil carbon.

The rate of leaf litter decomposition was marginally slower under the trees than in the adjacent grass-dominated areas (64.5\% vs. $60.3 \%$ remaining after 12 months), which agrees with previous studies, e.g., [13,31]. This was probably due to the cooler and drier conditions under the canopies. However, we did not specifically measure the moisture content of the litter, which could be more responsive to atmospheric vapor pressure deficit, which may have been lower under the tree canopies due to cooler conditions and higher humidity. Litter decomposition rate is often related to temperature [13,32-34]. Lower temperatures under the tree canopies was due to shading as photosynthetically active radiation under the canopies was approximately $15 \%$ of that in the open (data not shown). In addition to temperature, mean annual precipitation is related to litter decomposition, with precipitation increasing in importance for desert or semi-arid regions [35,36]. The reduction in soil moisture under tree canopies in our study was probably due in part to greater canopy and litter interception of incoming precipitation. Tree canopy and litter interception of precipitation are greater than for grasslands at other semiarid and subhumid sites [37-40], resulting in reduced soil moisture beneath tree canopies. In addition, transpiration of trees can be greater than for prairie vegetation [10]. Caterina et al. [11] found that J. virginiana trees could transpire all the rainfall that reaches the soil at a location near the current study. Acorn inputs were the largest contributor under the oak trees and potentially play an important role in carbon cycling. However, we did not measure the rate of acorn decomposition and their ultimate importance is unknown and influenced by annual variation in production and the extent of acorn herbivory by animals. 
In addition to environmental conditions, litter quality has a large effect on decomposition. In our study, decomposition of litter from tree species was greater than for grass ( $42 \%$ difference between J. virginiana and S. scoparium; 7\% difference between Q. marilandica and S. scoparium). Similarly, Gholz et al. [41] found faster decay rates for tree litter than grass litter. However, those results contrast with Norris et al. [13], who found a faster decomposition for S. scoparium than for J. virginiana. The authors attributed the lower decay rates of J. virginiana leaf litter in their study to greater lignin content. In addition to lignin, other factors influence the rate of litter decomposition, including C:N, phenolics, and other secondary compounds (we did not measure).

Greater annual inputs under tree canopies translated into greater accumulations of litter and duff on the soil surface even though the tree-derived litter decomposed more quickly. We found values of approximately $2200 \mathrm{~g} \mathrm{~m}^{-2}$ under trees and approximately $500 \mathrm{~g} \mathrm{~m}^{-2}$ beyond the trees (non-burned and non-grazed). These results agree with Norris et al. [13], who found a mass of litter layer (Oi and Oa horizon) of $2628 \mathrm{~g} \mathrm{~m}^{-2}$ under J. virginiana forests. Along with lower light availability, the greater duff/litter layer under the trees probably contributed to the reduced herbaceous productivity under the trees [42-44].

While beyond the scope of this study, the next step for this research is scaling results to the landscape based on aerial images or stand-level sampling. To provide an value to permit scaling, we estimated the carbon increase associated with an individual tree by weighting carbon content at each point by the area represented by each point. Doing so resulted in an increase in soil carbon of $4.6 \%$ under a tree of average size in our study. To calculate this, we used an average canopy spread of $9 \mathrm{~m}$ and applied the average carbon stock at each point to either an inner circle with a radius of $1.125 \mathrm{~m}$ (point 1) or concentric rings with an area spanning between radii of 1.125 and $3.375 \mathrm{~m}$ (point 2) and radii between 3.374 and $5.625 \mathrm{~m}$ (point 3). The result was $56.9 \mathrm{~kg} \mathrm{~m}^{-2}$ carbon under the tree's influence as compared to $54.4 \mathrm{~kg} \mathrm{~m}^{-2}$ measured beyond the tree. Because the areas under the outer portion of the canopy (point 3) had lower carbon stock than points 1 and 2, but the largest area, this mutes the impact somewhat. However, the effects will continue to get larger with the length of time and canopy expansion. For trees of similar species and sizes, this value could be used to estimate stand-level changes based on the percent aerial coverage, up to the point where tree density reaches a point where tree influences overlap.

\section{Conclusions}

Juniperus virginiana and Q. marilandica are two tree species that are encroaching grasslands in central Oklahoma. Although Q. marilandica trees receive less attention from land managers and researchers, the encroachment of both species increased soil carbon stock, primarily likely due to increased carbon inputs from litter and roots. The presence of the tree canopy in the grassland altered local environmental conditions, decreasing soil temperature and soil moisture. Tree-based litter decomposed faster than grass when measured in the same environment while litter decomposition under the tree trunk was marginally slower than away from it, suggesting that the rate of litter decomposition was not the primary factor affecting soil carbon stock. The lesser amounts of soil carbon near the drip line than near the trunk may be a consequence of less time of influence from expanding tree canopies or lessor amounts of recent litter inputs. If the afforestation process continues and the density and canopy size of encroaching trees continue to increase, spatially separated tree influences will merge, resulting in less heterogeneity and greater soil carbon.

Supplementary Materials: The following are available online at http://www.mdpi.com/1999-4907/10/4/329/s1, Figure S1: Soil surface temperature at different distances from the tree trunk for isolated $Q$. marilandica and J. virginiana encroaching the prairie, Figure S2: Soil temperature $5 \mathrm{~cm}$ soil depth at different distances from the tree trunk for isolated $Q$. marilandica and J. virginiana encroaching the prairie, Figure S3: Soil moisture at different distances from the tree trunk for isolated Q. marilandica and J. virginiana encroaching the prairie.

Author Contributions: V.C.N.B., R.E.W., and C.B.Z. conceived and designed the study; V.C.N.B. collected the data; V.C.N.B. and R.E.W. analyzed the data; V.C.N.B, R.E.W., and C.B.Z. wrote the paper. 
Acknowledgments: Special thanks to: OSU interns Giovanni Serreau and Caren Mendonica. This work was supported by USDA-NIFA grant 2014-67010-21653, the Oklahoma Agricultural Experiment Station, and McIntire Stennis project OKL0 2929.

Conflicts of Interest: The authors declare no conflict of interest. The founding sponsors had no role in the design of the study; in the collection, analyses, or interpretation of data; in the writing of the manuscript, and in the decision to publish the results.

\section{References}

1. Scholes, R.J.; Archer, S.R. Tree-grass interactions in savannas. Ann. Rev. Ecol. Syst. 1997, 28, 517-544. [CrossRef]

2. Briggs, J.M.; Hoch, G.A.; Johnson, L.C. Assessing the rate, mechanisms, and consequences of the conversion of tallgrass prairie to Juniperus virginiana forest. Ecosystems 2002, 5, 578-586. [CrossRef]

3. Archer, S.R.; Andersen, E.M.; Predick, K.I.; Schwinning, S.; Steidl, R.J.; Woods, S.R. Woody plant encroachment: Causes and consequences. In Rangeland Systems; Briske, D., Ed.; Springer: College Station, TX, USA, 2017; pp. 25-84.

4. Houghton, R.A.; Hackler, J.L.; Lawrence, K.T. The U.S. carbon budget: Contributions from land-use change. Science 1999, 285, 574-578. [CrossRef] [PubMed]

5. Wang, J.; Xiao, X.; Yuanwei, Q.; Doughty, R.B.; Dong, J.; Zou, Z. Characterizing the encroachment of juniper forests into sub-humid and semi-arid prairies from 1984 to 2010 using PALSAR and Landsat data. Remote Sens. Environ. 2018, 205, 166-179. [CrossRef]

6. Abrams, M.D. Fire and the development of oak forests. Bioscience 1992, 42, 346-353. [CrossRef]

7. Limb, R.F.; Engle, D.M.; Alford, A.L.; Hellgren, E.C. Tallgrass prairie plant community dynamics along a canopy cover gradient of eastern redcedar (Juniperus virginiana L.). Rangel. Ecol. Manag. 2010, 63, 638-644. [CrossRef]

8. Zou, C.; Caterina, G.; Will, R.E.; Stebler, E.; Turton, D. Canopy interception for a tallgrass prairie under juniper encroachment. PLOS ONE 2015. [CrossRef] [PubMed]

9. Zou, C.B.; Turton, D.J.; Will, R.E.; Engle, D.; Fuhlendorf, S. Alteration of hydrological processes and streamflow with juniper (Juniperus virginiana) encroachment in a mesic grassland catchment. Hydrol. Proc. 2014, 28, 6173-6182. [CrossRef]

10. Qiao, L.; Zou, C.; Stebler, E.; Will, R. Woody plant encroachment reduces annual runoff and shifts runoff mechanisms in the tallgrass prairie, USA. Water Resour. Res. 2017, 53. [CrossRef]

11. Caterina, G.L.; Will, R.E.; Turton, D.J.; Wilson, D.S.; Zou, C.B. Water use of Juniperus virginiana tree encroached into mesic prairies in Oklahoma, USA. Ecohydrology 2013, 7, 1124-1134.

12. Chapman, R.N.; Engle, D.M.; Masters, R.E.; Leslie, D.M., Jr. Tree invasion constrains the influence of herbaceous structure in grassland bird habitats. Ecoscience 2004, 11, 55-56. [CrossRef]

13. Norris, M.D.; Blair, J.M.; Johnson, L.C. Land cover change in eastern Kansas: Litter dynamics of closed-canopy eastern redcedar forests in tallgrass prairie. Can. J. Bot. 2001, 79, 214-222.

14. Norris, M.D.; Blair, J.M.; Johnson, L.C.; McKane, R.B. Assessing changes in biomass, productivity, and C and $\mathrm{N}$ stores following Juniperus virginiana forest expansion into tallgrass prairie. Can. J. For. Res. 2001, 31, 1940-1946. [CrossRef]

15. McKinley, D.C.; Blair, J.M. Woody plant encroachment by Juniperus virginiana in a mesic native grassland promotes rapid carbon and nitrogen accrual. Ecosystems 2008, 11, 454-468. [CrossRef]

16. Linneman, J.S. Studies of Eastern Redcedar Ecology in Central Oklahoma. Master's Thesis, Oklahoma State University, Stillwaer, OK, USA, 2004.

17. Pierce, A.M.; Reich, P.B. The effect of eastern red cedar (Juniperus virginiana) invasion and removal on a dry bluff prairie ecosystem. Biol. Invasions 2010, 12, 241-252. [CrossRef]

18. Reich, P.B.; Peterson, D.W.; Wedin, D.A.; Wrage, K. Fire and vegetation effects on productivity and nitrogen cycling across a forest-grassland continuum. Ecology 2001, 82, 1703-1719.

19. Guo, L.B.; Gafford, R.M. Soil carbon stocks and land use change: A meta analysis. Glob. Chang. Biol. 2002, 8, 345-360. [CrossRef]

20. Klemmedson, J.O.; Tiedemann, A.R. Influence of western juniper development on distribution of soil and organic layer nutrients. Northwest Sci. 2000, 74, 1-11.

21. Hibbard, K.A.; Archer, S.; Schimel, D.S.; Valentine, D.W. Biogeochemical changes accompanying woody plant encroachment in a subtropical savanna. Ecology 2001, 82, 1999-2011. [CrossRef] 
22. Bates, J.D.; Svejcar, T.J.; Miller, R.F. Effects of juniper cutting on nitrogen mineralization. J. Arid Environ. 2002, 51, 221-234. [CrossRef]

23. Smith, D.L.; Johnson, L.C. Expansion of Juniperus virginiana L. in the Great Plains: Changes in soil organic carbon dynamics. Glob. Biogeochem. Cycles 2003, 17, 1062. [CrossRef]

24. Grunzweig, J.M.; Gelfand, I.; Fried, Y.; Yakir, D. Biogeochemical factors contributing to enhanced carbon storage following afforestation of a semi-arid shrubland. Biogeosciences 2007, 4, 891-904. [CrossRef]

25. Jackson, R.B.; Banner, J.L.; Jobbagy, E.G.; Pockman, W.T.; Wall, D.H. Ecosystem carbon loss with woody plant invasion of grasslands. Nature 2002, 418, 623-626. [CrossRef]

26. Lang, G.E. Litter dynamics in a mixed oak forest on the New Jersey Piedmont. Bull. Torrey Bot. Club 1974, 101, 277-286. [CrossRef]

27. Ansley, R.J.; Boutton, T.W.; Jacoby, P.W. Root biomass and distribution patterns in a semi-arid mesquite savanna: Responses to long-term rainfall manipulation. Rangel. Ecol. Manag. 2014, 67, 206-218. [CrossRef]

28. Steinaker, D.F.; Wilson, S.D. Belowground litter contributions to nitrogen cycling at a northern grassland-forest boundary. Ecology 2005, 86, 2825-2833. [CrossRef]

29. Guo, L.B.; Wang, M.; Gifford, R.M. The change of soil carbon stocks and fine root dynamics after land use change from a native pasture to a pine plantation. Plant Soil 2007, 299, 251-262. [CrossRef]

30. Gill, R.A.; Jackson, R.B. Global patterns of root turnover for terrestrial ecosystems. New Phytol. 2000, 147, 13-31. [CrossRef]

31. Köchy, M.; Wilson, S.D. Litter decomposition and nitrogen dynamics in aspen forest and mixed-grass prairie. Ecology 1997, 78, 732-739. [CrossRef]

32. Hunt, H.; Ingham, E.; Coleman, D.; Elliot, E.; Reid, C. Nitrogen limitation of production and decomposition in prairie, mountain meadow, and pine forest. Ecology 1988, 69, 1009-1016. [CrossRef]

33. Mudrick, D.A.; Hoosein, M.; Hicks, R.R.; Townsend, E.C. Decomposition of leaf litter in an Appalachian forest: Effects of leaf species, aspect, slope position and time. For. Ecol. Manag. 1994, 68, 231-250. [CrossRef]

34. Shaw, M.R.; Harte, J. Control of litter decomposition in a subalpine meadow-sagebrush steppe ecotone under climate change. Ecol. Appl. 2001, 11, 1206-1223.

35. Couteaux, M.; Bottner, P.; Berg, B. Litter decomposition, climate and litter quality. Trends Ecol. Evol. 1995, 10, 63-66. [CrossRef]

36. Zhang, D.; Hui, D.; Luo, Y.; Zhou, G. Rates of litter decomposition in terrestrial ecosystems: Global patterns and controlling factors. J. Plant Ecol. 2008, 1, 85-93. [CrossRef]

37. Johnsen, T.N. One-seed juniper invasion of northern Arizona grasslands. Ecol. Monogr. 1962, 32, $187-207$. [CrossRef]

38. Skau, C. Interception, throughfall, and stemflow in Utah and alligator juniper cover types of northern Arizona. For. Sci. 1964, 10, 283-287.

39. Belsky, A.; Amundson, R.; Duxbury, J.; Riha, S.; Ali, A.; Mwonga, S. The effects of trees on their physical, chemical and biological environments in a semi-arid savanna in Kenya. J. Appl. Ecol. 1989, 26, 1005-1024. [CrossRef]

40. Breshears, D.D.; Rich, P.M.; Barnes, F.J.; Campbell, K. Overstory-imposed heterogeneity in solar radiation and soil moisture in a semiarid woodland. Ecol. Appl. 1997, 7, 1201-1215. [CrossRef]

41. Gholz, H.L.; Wedin, D.A.; Smitherman, S.M.; Harmon, M.E.; Parton, W.J. Long-term dynamics of pine and hardwood litter in contrasting environments: Toward a global model of decomposition. Glob. Chang. Biol. 2000, 6, 751-765. [CrossRef]

42. Hiers, J.K.; O'Brien, J.J.; Will, R.E.; Mitchell, R.J. Forest floor depth mediates understory vigor in xeric Pinus palustris ecosystems. Ecol. Appl. 2007, 17, 806-814. [CrossRef]

43. Van Els, P.; Will, R.E.; Palmer, M.W.; Hickman, K.R. Changes in forest understory associated with Juniperus encroachment in Oklahoma, USA. Appl. Veg. Sci. 2010, 13, 356-368.

44. Feltrin, R.P.; Will, R.E.; Meek, C.R.; Masters, R.E.; Waymire, J.; Wilson, D.S. Relationship between photosynthetically active radiation and understory productivity across a forest-savanna continuum. For. Ecol. Manag. 2016, 374, 51-60. [CrossRef]

(C) 2019 by the authors. Licensee MDPI, Basel, Switzerland. This article is an open access article distributed under the terms and conditions of the Creative Commons Attribution (CC BY) license (http://creativecommons.org/licenses/by/4.0/). 